\title{
The genus Neottia, an early step in shift from autotrophy to mycoheterotrophy in orchids?
}

\author{
Tamara Malinová ${ }^{1,2}$, Milan Kotilíne ${ }^{\mathrm{k} 1}$, Jana Jersáková ${ }^{1,2^{*}}$, Francois-XaVier Joly ${ }^{1}$ \\ \& MARC-AndRÉ Selosse ${ }^{3}$
}

'Faculty of Science, University of South Bohemia, Branišovská 31, CZ-370 05 České Budějovice, Czech Republic; ${ }^{2}$ CzechGlobe, Academy of Sciences of the Czech Republic, Bělidla 986, CZ-603 00 Brno, Czech Republic; ${ }^{3}$ Centre d'Ecologie Fonctionnelle et Evolutive (CNRS, UMR 5175) 1919 Route de Mende, Montpellier, France

*Author for correspondence: jersa@centrum.cz

Many plant families evolved mycoheterotrophy as a way of gaining nutrients, but the evolution of such nutritional shift has been little studied. We investigated mycorrhizal associations and a nutritional mode of two orchid species, a common ecological generalist Neottia ovata and N. cordata, a species of peatbog spruce forests. The species are closely related to a nongreen $N$. nidus-avis, associated with ectomycorrhizal Sebacinales, clade A. We investigated the course of germination at 18 sites in the Czech Republic, analyzed fungal spectra of both seedlings and $39 \mathrm{~N}$. ovata and $21 \mathrm{~N}$. cordata adults growing in 32 European sites in different habitats and measured the natural content of stable isotopes. Seeds of both species suffered high mortality during two years of in situ germination. Whereas $N$. ovata produced few protocorms at both
$N$. ovata and $N$. cordata localities, $N$. cordata never reached a protocorm stage. We found Sebacinales, clade $\mathrm{B}$, in both seedlings and adults, independent of habitat type and site geography. The spectra of accompanying fungal species differed according to habitat: the meadow individuals associated frequently with saprophytic Tulasnellaceae, whereas the forest individuals associated more often with ectomycorrhizal fungi. Natural content of stable $13 \mathrm{C}$ and $15 \mathrm{~N}$ isotopes in forest specimens, however, did not indicate significant nutrient gain by mycoheterotrophy. Neottia species form mycorrhiza with Sebacinales, clade $\mathrm{B}$, in various habitats. This association together with the co-occurrence of ectomycorrhizal fungi at forest sites could serve as a predisposition for the shift to full mycoheterotrophy in Neottia.

\section{Endophytic fungi associated with natural populations of Vanilla species in south- west Colombia}

\author{
Ana Teresa Mosquera-Espinosa ${ }^{1,2^{*}}$, J. Tupac Otero $^{1,3,4}$ \& Nicola S. Flanagan ${ }^{1,2}$
}

${ }^{1}$ Research Group in Orchids, Ecology and Plant Systematics, Universidad Nacional de Colombia, Palmira, Colombia; ${ }^{2}$ Biology Program, Pontificia Universidad Javeriana, Cali, Colombia; ${ }^{3}$ Biological Sciences Department,

Universidad Nacional de Colombia, Palmira, Colombia; ${ }^{4}$ Environmental Studies Institute (IDEA Palmira), Universidad Nacional de Colombia, Palmira, Colombia; *Author for correspondence: fitopatologia@hotmail.com

The genus Vanilla (Orchidaceae) is of economic interest as the source of the natural vanilla fragrance, derived principally from cultivated plants of the species $V$. planifolia. The clade of fragrant species ( $V$. subgenus Xanata, section Xanata) has a natural distribution in the Neotropics. Work in this research group has identified populations of ten Vanilla species in the region. Orchid species, including those of Vanilla, have an intimate relationship with mycorrhizal fungi to provide nutrients during seedling establishment and often in mature plants. Colombia has over 3,300 orchid species, but little is known regarding the diversity of orchid mycorrhizal fungi essential for the establishment and survival of these species. We aim to characterize the diversity of fungi associated with the root system of adult plants of Vanilla species native to the diverse ecosystems of south-west Colombia, which include both humid tropical rainforest and sub-xerophytic habitats. Three methodologies are being implemented: 1) isolation of fungi from root portions colonized with mycorrhizal fungi; 2) isolation from single pelotons; and 3) identification of fungi present through direct PCR amplification using 
fungal specific PCR primers. All fungi are identified by DNA sequencing of the ITS locus. Additionally, fungi are evaluated for their mycorrhizal potential through assays of symbiotic germination of Vanilla seeds. The results support the bioprospecting focused on the con- servation of these valuable plant genetic resources, as well as the development of sustainable cultivation techniques. This study is also an important contribution to the incipient studies of microbial diversity in the megabiodiverse country of Colombia.

\title{
Hongos micorrízicos de orquídeas en poblaciones naturales en los departamentos del Valle del Cauca y Antioquia, Colombia
}

\author{
Ana Teresa Mosquera-Espinosa ${ }^{1,2^{*}}$, Paul Bayman ${ }^{3} \&$ J. Tupac Otero ${ }^{1,4,5}$
}

${ }^{1}$ Research Group in Orchids, Ecology, and Plant Systematics, Universidad Nacional de Colombia, Palmira, Colombia;

${ }^{2}$ Biology Program, Pontificia Universidad Javeriana, Cali, Colombia; ${ }^{3}$ Biology Department, University of Puerto

Rico-Rio Piedras; ${ }^{4}$ Biological Sciences Department, Universidad Nacional de Colombia, Palmira, Colombia;

${ }^{5}$ Environmental Studies Institute (IDEA Palmira), Universidad Nacional de Colombia, Palmira, Colombia

*Autor para correspondencia: fitopatologia@hotmail.com

En Colombia existe una amplia diversidad de especies de orquídeas (cerca de 3.500 especies), muchas aún no descritas. También, dentro de la diversidad se incluyen los hongos micorrízicos del género-forma Rhizoctonia y sus teleomorfos en los géneros Thanatephorus, Sebacina, Ceratobasidium y Tulasnella. En algunas orquídeas terrestres de zonas templadas se asocian con otros grupos de hongos. Para esta zona tropical es poco lo que se conoce sobre sus hongos micorrízicos y aún no es claro si la mayoría de orquídeas, se asocian con los mismos micosimbiontes o si existen otros cumpliendo tal actividad. Para contestar esta pregunta se tomaron secciones de raíces micorrizadas, de las cuales se aislaron y cultivaron hongos para secuenciar ADN de la región ITS nuclear ribosomal. Igualmente se realizaron ensayos de germinación simbiótica. Estudios desarrollados por el Grupo mostraron a Ceratobasidium como el género de hongo micorrízico predominante en algunas orquídeas de Colombia con hábito terrestre, epífito y hemiepifítico (Vanilla spp., en raíces terrestres). Las secuencias de hongos de orquídeas epífitas se relacionaron estrechamente con secuencias de hongos de orquídeas epífitas de Puerto Rico. Lo anterior sugiere que Ceratobasidium está presente como micorrízico en orquídeas independiente del hábitat de la planta y su ubicación geográfica.

\section{Selección de rasgos florales en Rodriguezia granadensis (Lindl.) Rchb.f. (Orchidaceae): estudio de la eficacia biológica en una especie polimórfica}

\author{
Nhora Helena Ospina-Calderón ${ }^{1,2 *}$, J. Tupac Otero ${ }^{2,3,4} \&$ R. L. Tremblay ${ }^{5}$
}

'Facultad de Ciencias Naturales, Programa de Ecología, Fundación Universitaria de Popayán, Popayán, Colombia; ${ }^{2}$ Grupo de Investigación en Orquídeas, Ecología y Sistemática Vegetal. Universidad Nacional de Colombia Sede

Palmira, Colombia; ${ }^{3}$ Facultad de Ciencias Agropecuarias, Departamento de Ciencias Biológicas, Universidad Nacional de Colombia Sede Palmira, Colombia; ${ }^{4}$ Instituto de Estudios Ambientales IDEA, Palmira, Colombia. Universidad Nacional de Colombia Sede Palmira, Colombia; ${ }^{5}$ Departamento de Biología, Universidad de Puerto Rico, Humacao; *Autor para correspondencia: nhora-helena@yahoo.com

La supervivencia de las especies depende en parte de su dinámica poblacional y sus característica fenotípicas. El proceso de selección natural es un mecanismo que puede influenciar la producción de progenies. Se estudió la biología y demografía de dos poblaciones de Rodriguezia granadensis (Lindl.) Rchb. f. en la zona de la Reserva Forestal Bosque de Yotoco y en el corregimiento El Dorado, Colombia, 